\title{
The Long Road Home: Protracted Refugee Situations in Africa
}

Since the early 1990s, the international response to refugee emergencies has focused on delivering humanitarian assistance to war-affected populations, and encouraging large-scale repatriation programmes in high-profile regions such as the Balkans, the African Great Lakes or, recently, Darfur and Chad. The majority of today's over 12 million refugees, however, are trapped in protracted refugee situations. Such situations - often characterised by long periods of exile, stretching to decades for some groups - occur on most continents in environments ranging from camps to rural settlements and urban centres. In addition, a large proportion of the world's internally displaced people, around $25 \mathrm{~m}$ (about half of them in Africa), have been displaced for a decade or more. ${ }^{x}$

Protracted refugee populations are a critical element in continuing conflict and instability. They obstruct peace processes and undermine attempts at economic development. Recurring refugee flows are also a source of international conflict. They cause instability in neighbouring countries and trigger intervention; sometimes refugee camps are used as bases by armed groups that engage in insurgency, resistance and terrorism. The militarisation of refugee camps creates a security problem for the country of origin, the host country and the international community. Security concerns such as arms trafficking, drug smuggling, trafficking in women and children, and the recruitment of child soldiers and mercenaries arise in camps hosting long-term refugees.

In East and West Africa, South Asia, Southeast Asia, the Caucasus, Central Asia and the Middle East, refugees and internally displaced people remain 
uprooted, unprotected and without any clear prospect of a solution to their plight. The United Nations High Commission for Refugees (UNHCR) estimates that there were 38 protracted refugee situations in 2003. ${ }^{2}$ These situations accounted for a total refugee population of $6.2 \mathrm{~m}$. With a global refugee population of $9.6 \mathrm{~m}$ at the end of 2003 , over $64 \%$ of the world's refugees were in protracted refugee situations. UNHCR also estimates that the average duration of major refugee situations 'has increased from nine years in 1993 to 17 years at the end of $2003^{\prime}{ }^{3}$ These figures indicate that protracted refugee situations are both growing in number and lasting longer without being resolved.

The bulk of refugees in these regions - Somalis, Sudanese, Burundians, Iraqis, Afghans and Burmese - come from countries with protracted histories of conflict and persecution. The physical and economic insecurity that most of these refugees experience, coupled with a lack of resettlement opportunities, has led large numbers of asylum seekers and migrants to move on to Western countries and use illegal means of entry, including smuggling and trafficking organisations.

Africa hosts the most complex and pressing of these protracted refugee situations. The majority of the more than three million African refugees have been in exile for over ten years. These include Sahrawis, Burundians, Liberians, Eritreans, Somalis and Southern Sudanese.

Kenya and Tanzania have two of the most challenging protracted refugee situations in Africa. ${ }^{4}$ Kenya has hosted significant numbers of Somali and Sudanese refugees since 1991, while Tanzania has hosted hundreds of thousands of refugees fleeing successive wars in Burundi and Rwanda since 1959. Both the governments and citizens of these host countries have negative views of refugees, who are associated with problems of security, violence and crime and are viewed as threats to social cohesion and employment, or even as posing a threat of insurgency or terrorism. Such perceptions have resulted in growing xenophobia and made the host governments' policies increasingly popular with the voting public.

\section{A half-century of African refugees}

Refugee movements have been a central feature of the continent's politics since independence. Large refugee movements resulted not only from the wars of national liberation in Southern Africa during the 1960s and early 1970s, but also from civil conflict in newly independent states such as Sudan, Rwanda, Congo and Burundi. All of these conflicts involved spill-over into neighbouring countries, ${ }^{5}$ which often viewed fleeing refugees as a national security threat. ${ }^{6}$ The presence of large numbers of disaffected refugees in border areas strained relations between sending and receiving states. Throughout the 1960s and early 1970s, Rwanda and Sudan, for example, believed that 
rebel groups would exploit refugees who had fled from their home countries. As these refugee situations became protracted, these concerns proved to be justified. In the case of Sudan, neighbouring countries became alarmed at the threats posed to their own internal security by the presence of Sudanese refugees. On several occasions in the early 1960s, the Sudanese military entered border areas in Uganda and Ethiopia, seized refugees, and returned them to Sudan. Uganda gave direct and indirect assistance to the Sudanese refugees and rebels. Consequently, relations between Uganda and Sudan came under severe strain.7 By contrast, Rwandan refugees were generously received into Tanzania in the early $1960 .^{8}$ Motivated by a strong sense of pan-Africanism, and recognising the benefits of settling large refugee populations on underused land, the Tanzanian government under Julius Nyerere encouraged the settlement of the 1959 Rwandan refugees and, subsequently, those refugees fleeing conflict in Burundi in 1972. Under Nyerere's ujamaa philosophy, based on self-reliance and African socialism, the reception and integration of refugees from Rwanda and Burundi was regarded not only as a means of highlighting the failures of neighbouring regimes, but also as being in the interests of regional development.

The majority of African refugees in this period were fleeing wars of national liberation. Refugees from the Portuguese territories of Angola, Mozambique and Guinea-Bissau caused significant security concerns for host states. The presence of Angolan refugees in Zaire (now the Democratic Republic of the Congo) led Portugal to accuse Zaire of protecting 'terrorists' and of providing material and moral support as well as safe bases for Angolan rebel movements. Not only did Zaire provide refuge to Angolans fleeing Portuguese military campaigns, it also permitted the Angolan government-in-exile and other nationalist organisations to operate within its borders. Likewise, the Tanzanian government under Nyerere supported a number of liberation movements during the 1960 s and early 1970s. The capital Dar es Salaam was the home for the Organisation of African Unity's Liberation Committee, where most major movements across Africa were represented. The Tanzanian government permitted and encouraged the Mozambican Liberation Front (FRELIMO) forces to use refugees as resources in their anti-colonial struggle and to establish bases in Tanzania. In retaliation, Portugal made punitive incursions, including bombing raids by the Portuguese air force, against Tanzania, and heavily mined the Mozambique-Tanzania border.

The US and USSR gave political and military support to the various African independence movements in a bid to exert influence. The most direct means of exerting influence was through assistance to refugee populations, which contributed to the establishment of semi-permanent settlements across the continent. Superpower engagement became much more pronounced 
following the withdrawal of the Portuguese from their colonies in the mid1970 and the escalation of conflict in the Horn of Africa.

By the end of the 1970s, through to the mid-1980s, the renewal of EastWest tensions, superpower rivalry and external manipulation of civil conflicts resulted in massive refugee flows. The superpowers played an important role in conflicts in Angola, Mozambique and the Horn of Africa - either by proxy in an attempt to bolster regional allies, or by expanding regional and ethnic conflicts into 'internationalised' civil wars. Moscow and Washington backed either established regimes in the countries of origin or, more typically, exiled fighters seeking to overthrow those regimes. Superpower engagement accelerated local arms races and prolonged the conflicts, dramatically increasing the number of refugees in Africa, which rose to over $4 \mathrm{~m}$ by 1980.9 These refugee communities became entrenched for political purposes, as their camps and settlements benefited from significant material assistance intended to support one or another faction in the conflict.

Politicisation of refugee problems in Africa during the 1980s precluded an easy solution to the refugee dilemma. The three traditional solutions - resettlement, local settlement and integration, and repatriation - no longer proved adequate. There were no compelling political or ideological reasons for Western states to resettle large numbers of refugees from Africa. Moreover, as a result of diminishing international support for long-staying refugee populations, local settlement began to be perceived by most African host governments as politically and economically infeasible. Finally, neither donor governments nor most countries of origin had any interest in promoting repatriation. So long as refugees were engaged in guerrilla warfare against enemy countries, the United States showed little interest in largescale return. Likewise, countries of origin were in no hurry to facilitate repatriation, particularly when the refugee population partially consisted of enemies or guerrilla resistance movements.

This situation was compounded by the disengagement of the superpowers from Africa in the late 1980 . This disengagement, coupled with a rising preoccupation with potential refugee flows from Eastern Europe and the Balkans, led to the neglect of a number of African refugee situations, especially those resulting from previous proxy wars. Notwithstanding repatriation successes in Namibia and Mozambique, refugee populations from Angola, Burundi, Ethiopia, Somalia and Sudan remained unaddressed, placing a significant strain on host governments and communities. Many protracted refugee situations in Africa today stem from this period. What little assistance was directed to African states from bilateral donors and international financial institutions 
became conditional on democratisation and economic liberalisation, thereby putting new pressures on African states and limiting their range of policy options. Finally, the changing nature of conflict in Africa, coupled with the lack of engagement of the United States and others following the withdrawal of US forces from Somalia in 1993, resulted in new conflicts and a dramatic escalation in the number of refugees, rising to almost $7 \mathrm{~m}$ by the mid-1990s. ${ }^{10}$ There are thus more unresolved refugee situations in Africa today, while many host states face significant economic and political pressures. ${ }^{11}$

Many host governments draw attention to the problem of small-arms trafficking and perceive it to be associated with foreign populations, particularly protracted refugee groups, from adjoining war-zones or failed states. As a consequence, most African governments have warehoused refugees in an estimated 170 camps for over a decade, exacerbating local and regional insecurity. At the same time, tens of thousands of refugees live clandestinely in urban areas, avoiding contact with authorities and existing without legal status. ${ }^{12}$ The growing concerns of host governments illustrate why the international community should address the question of protracted refugee situations not only as an issue human rights for refugees left in limbo but also as a rising issue of national and regional security.

\section{Kenya and Tanzania}

Kenya has hosted large numbers of refugees as a result of state collapse in Somalia and continuing civil war in Sudan. The total number of Somali refugees in Kenya exceeded 400,000 in 1994 but has been relatively stable at 135,000 since 1996 . The overwhelming majority of these refugees live in three camps near the town of Dadaab, in the Northeast Province, approximately $80 \mathrm{~km}$ from the Kenya-Somalia border. During the 1990s, these camps were renowned as the most violent in the world, with rape, murder and armed robbery almost daily occurrences. ${ }^{13}$ Violence was also endemic in the surrounding areas, as bands of shiftas, or bandits, attacked convoys of humanitarian relief, aid workers and refugees collecting firewood.

The spill-over of insecurity into the local population in the 1990s was exacerbated by the influx of weapons brought in by Somali warlords. According to Kathi Austin, who carried out research at Dadaab during this period, 'local Kenyan police tasked with security were afraid to go into the camps at night; UNHCR and NGO compounds were fenced-in and protected with enforced curfews; and NGOs had to be escorted to and from the camps to carry-out their operations'. ${ }^{14}$

Many in the government in Nairobi perceive the Somali refugee population as a security threat, reinforcing the policy of containing them in isolated refugee camps. ${ }^{15}$ This perception was reinforced after reported links between 
the residents of the Dadaab camps and the terrorist attacks in Kenya in 1998 and 2002. Shortly after the 2002 attack in Mombasa, US intelligence sources claimed that a Somali-based Islamic organisation called al-Ittihad al-Islamiya, which had links to the al-Qaeda network, was responsible for the attacks. ${ }^{16}$ While this link has subsequently proven to be tenuous, the perception of Somali refugees as a threat nonetheless remains.

Tanzania hosts a number of refugee populations, including successive influxes from Burundi, Rwanda and Zaire (now the Democratic Republic of the Congo). Unlike Kenya's relatively recent experience with refugees, Tanzania has continuously hosted refugees from neighbouring countries since gaining independence in 1964. The largest group, totalling some 600,000 , is from Burundi. About 180,000 Burundese originate from the exodus fleeing the 1972 civil war.

Over 100,000 Burundian refugees who have been living in Kibondo in western Tanzania since 1993, posing the greatest concerns to Dar es Salaam.17 Most pressing have been allegations that armed elements from Burundian rebel groups are based in the camps, where they carry out fundraising and recruitment. ${ }^{18}$ These allegations have been denied by the Tanzanian government and steps taken to increase the ability of the local security forces to screen for armed elements among the refugees. However, allegations of rebel activities in camps continue.

The protracted presence of Burundian refugees has led to a proliferation of small arms, not only in the refugee-populated areas, but also in large urban areas, especially Dar es Salaam. In September 2003, Tanzanian President Benjamin Mkapa publicly blamed refugees for the increase in armed crime and trafficking of weapons, and cited this concern as a justification for Tanzania's increased restriction on refugees and insistence on early repatriation. There is also a common belief that the presence of refugees has led to rises in disease and environmental degradation, and placed a significant strain on local infrastructure and public services. Relations between refugees and local authorities have deteriorated, and a sense of insecurity now prevails in refugee-populated areas.

The current situation

African states no longer grant liberal asylum as a matter of course. ${ }^{19}$ Refugees are no longer viewed as victims of national liberation struggles, and African solidarity with refugees has been strained. Local populations in refugee-populated areas feel aggrieved that refugees receive such basic services as health care and primary education while their own access to these basic services has been cut as a consequence of economic liberalisation. Refugees are seen as a security concern at the national level, where governments express concerns about small- 
arms proliferation and the spill-over of conflict, and at the local level, where communities see them as the cause of increased crime and insecurity.

Host governments have responded by increasingly restricting the quantity and quality of asylum on offer. They have closed borders to new arrivals, engaged in refoulement, or forced return, and, in exceptional circumstances, expelled entire refugee populations. Refugees are sent to isolated and insecure border areas and warehoused in dangerous camps until a solution can be found. Host states have almost universally abdicated responsibility for refugees to international agencies such as UNHCR. In exchange for opening their borders to refugees, states like Kenya and Tanzania now stipulate that refugees from neighbouring countries will only benefit from temporary asylum, and must remain in camps until a solution can be found in another country.

The isolation of refugees in camps not only denies them many basic rights; ${ }^{20}$ it can also compound states' security concerns. Refugees in Kenya and Tanzania are forbidden to leave the camps and their immediate environs. It is illegal for refugees in western Tanzania, for example, to travel more than $4 \mathrm{~km}$ from the camps. They are no longer able earn wages in the surrounding villages and are thus fully dependent on international assistance. Coupled with donor fatigue and frequent interruptions in the delivery of even basic assistance to the camps, this policy forces some refugees to turn to illegal activities, ranging from petty theft to prostitution and armed robbery. This further reinforces states' sense of vulnerability, leading to more restrictive measures against refugees.

\section{Security implications - direct and indirect}

Some security threats faced by the host states - spill-over of conflict and the presence of 'refugee warriors' ${ }^{21}$ - reflect a direct link between forced migration and violence, as the migrants themselves are actively engaged in armed campaigns typically, but not exclusively, against the country of origin. ${ }^{22}$ Such campaigns can potentially regionalise conflicts and drag host states into what were previously intra-state conflicts. This played a significant role in regionalisation of conflict during the Cold War. With the end of the Cold War, the logic has changed, but the relevance of refugee warriors remains, something brought home with particular force in the maelstrom of violence that gripped the Great Lakes region of Central Africa in 1994-96.

These direct causes of insecurity are best understood within the context of so-called failed states, as in Somalia, and the rise of warlordism, as in the case of Liberia during the 1990s. Armed groups hide behind the humanitarian character of refugee camps and settlements, and recruit among the disaffected displaced populations. ${ }^{23}$ There is a risk that humanitarian aid, including food, medical assistance and other support mechanisms, might be expropriated to support 
armed elements. Similarly, gangs and criminal networks may emerge within displaced and disenfranchised urban refugee populations. These groups take advantage of the transnational nature of refugee populations, of remittances from abroad and the marginal existence of urban refugees to further their goals. In both contexts, refugees provide cover for illicit activities ranging from prostitution and people smuggling to trade in small arms, narcotics and diamonds.

The consequences of such activities include cross-border attacks on both host states and countries of origin, and on humanitarian personnel, refugees and civilian populations. This can lead to serious bilateral and regional political and diplomatic tension. Cross-border flows are perceived by host states as encroachments on their national sovereignty, especially given the tenuous control of many central governments over their border regions. Finally, the activities of armed elements among refugee populations not only violate refugee-protection and human-rights principles, but can constitute threats to international peace and security. ${ }^{24}$ For example, the consequences of training and arming the Taliban and mujahadeen in refugee camps in Pakistan (by the United States and others) in previous decades highlights the potential threat to regional and international security posed by refugee warriors.

Both Kenya and Tanzania have raised significant concerns about the direct security threat posed by long-standing refugee populations. Kenya's porous borders and its position as a regional diplomatic and commercial centre made it a target of international terrorist attacks in 1998, with the bombing of the US Embassy in Nairobi, and in 2002, with attacks on Israeli interests in Mombasa. Kenya is also concerned about the flow of small arms, primarily from Somalia, into its territory, and especially into urban areas. Link with Islamic fundamentalism, a lack of central authority in Somalia and a long history of irredentism within its own ethnic Somali population lead Nairobi to view Somali refugees through a security prism.

The presence of armed elements in western Tanzania and allegations that refugee camps serve as a political and military bases for Burundian rebel groups have led to open hostilities, including a cross-border exchange of mortar fire, between Tanzania and Burundi. Politicians and police have raised concerns over a perceived rise in urban gun-crime resulting from the flow of small arms from Burundi. Consequently, the Tanzanian government has increased restrictions on Burundian refugees, is pushing for early repatriation, and has adopted the official policy that refugees should be restricted to safe havens in their country of origin.

\section{Indirect threats}

In cases like Tanzania, structural adjustment programmes have eliminated free access to health and education for local populations. Such services, however, 
are still provided free of charge to refugees. Tensions result. Competition over scarce resources, especially in the context of declining donor engagement in protracted refugee situations, can also be a source of conflict between refugees and the local population. More generally, the presence of refugees can exacerbate previously existing ethnic antagonisms and change the balance of power between groups in the host country. This concern about ethnic balance was made explicit in Macedonia's reluctance to accept Kosovar Albanian refugees in March 1999.25 Such indirect security consequences are potentially on the same scale as more direct threats.

But not all refugees are seen as threats. The question of which are, and why, may be partially answered by whether they are perceived as members of the local political community or as outsiders. Indeed,

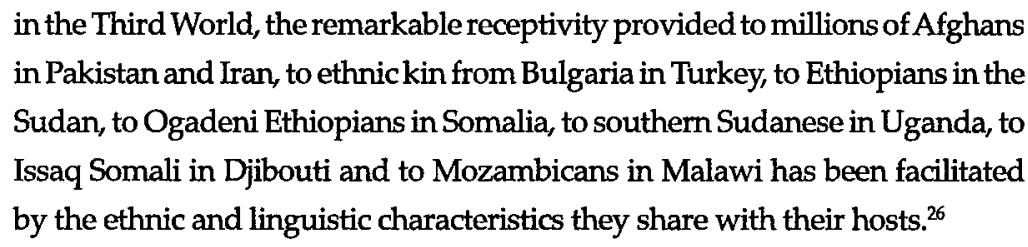

The importance of affinity and shared group identity cannot be overstated. If a host community perceives the incoming refugee as 'one of us', then positive and generous conceptions of distributive justice will apply. The empirical evidence is overwhelming.

Conversely, if refugees are seen as members of an 'out group', they are likely to receive a hostile reception. In cases where there is a division along ethnic, linguistic or religious lines, 'a major population influx can place precariously balanced multi-ethnic societies under great strain and may even threaten the political balance of power'. Indeed, refugees, 'as an out group, can be blamed for all untoward activities'. ${ }^{27}$ While crime rates may rise only in proportion to the rise in population, refugees increasingly are seen as the cause, and can also be blamed for poverty, unemployment, scarcity of resources and disease..$^{28}$

These dynamics have been evident in the dramatic restrictions on asylum that have been imposed by host states in Africa since the mid-1990s. Numerous reports have pointed to the absence of meaningful burden-sharing and growing xenophobia in many African countries as the key factors motivating restrictive asylum policies. ${ }^{29}$ Rather ironically, these xenophobic sentiments 
various policies. The result has been the adoption of anti-refugee platforms by political parties which result in anti-refugee policies and actions by governments. ${ }^{30}$

Just as politicians in Western Europe have recently faced increasing pressure to restrict entry, 'the rise of multiparty democracy in Africa ... has arguably diminished the autonomy of state elites in determining the security agenda' ${ }^{\prime 1}$ For example, the Tanzanian government's decision to close its border with Burundi was closely linked to the lead-up to the 1995 parliamentary and presidential elections. Opposition parties exploited local dissatisfaction with the government's handling of the asylum question and tried to demonstrate that they had the power to restore order and stability to border regions by expelling unpopular refugee populations. ${ }^{32}$

The presence of large numbers of refugees in a state's periphery may give that region a new significance. This is particularly true when the political geography of many African states is considered. ${ }^{33}$ Unlike European states, the power of African states is concentrated in economic centres; control over the periphery is limited. The presence of large refugee populations in these 'hinterlands', where the regime typically does not exercise effective control and where there is 'space for challengers to form large and sophisticated rebel armies', 34 is a serious concern.

\section{What to do}

The causes and consequences of refugee-related security concerns are diverse; responses must be varied. In the short term, direct security concerns must be addressed through supporting the (highly complex) separation and exclusion of armed elements within the refugee population. ${ }^{35}$ Specific disarmament measures, such as UN arms embargos, have to be enforced. Arms surpluses have to be collected; militias and warlords have to be demobilised and - in some cases - integrated into the national army and police; and arms syndicates and networks need to be broken.

Since 1998, UNHCR has developed a range of operational responses to deal with the problem of militarisation of refugee camps. Security experts have been deployed into selected African camps. In 1998 a 'security package' was implemented in western Tanzania that involved material support and training to local police. ${ }^{36} \mathrm{UNHCR}$ also moved Sierra Leonean and Liberian refugee camps in Guinea further from the border to protect refugees from attacks by armed elements, and supported the Guinean government in the formation of a special security force - which received training from Canadian federal police officers - to patrol these camps. While these actions helped create greater security for some of the refugee camps and communities in Tanzania and Guinea, they have 
not uniformly led to greater peace in the wider refugee-populated areas. ${ }^{38} \mathrm{~A}$ similar effort by UNHCR and the UN Department of Peacekeeping Operations (DPKO) in the Democratic Republic of the Congo in mid-2001 successfully separated armed elements from refugees. ${ }^{39}$

The future of such security initiatives depends on the practical partnerships and 'security packages' that UNHCR is able to form with the DPKO, governments and regional organisations. While discussions between DPKO and UNHCR have set the groundwork for future cooperation between the two offices, serious differences of approach and political and resource constraints remain. UNHCR and other humanitarian aid organisations fear that too close an association with the military compromises their impartiality and neutrality, while governments are reluctant to authorise military forces for such functions. Protection for refugees in militarised situations also depends critically on the willingness and ability of host states and countries of origin to observe international humanitarian norms regarding the treatment of refugees and non-combatants.

In the last two years the number of UN peacekeeping operations in Africa has increased dramatically. The UN Security Council has authorised new missions in Liberia and Burundi, strengthened existing ones in the Democratic Republic of the Congo, and authorised a large-scale mission to Sudan to support the implementation of a comprehensive peace accord signed at the end of 2004. These missions are overwhelmingly staffed by troops from developing countries and many commentators feel the UN is dangerously overstretched in its peacekeeping operations.

Such African missions are so-called 'complex peacekeeping operations', involving multiple tasks and combining military and civilian components..$^{\circ}$ Building up regional peacekeeping capabilities goes hand in hand with development initiatives to help restore stability in war-torn regions. But, as Mats Berdal points out, neither the DPKO nor under-resourced peacekeeping forces from developing countries have adequate capacity (especially in logistics) to sustain this level of multiple operations effectively.41

One effort to fill this gap is the agreement at the June 2004 European Union summit in Brussels to create, by 2007, a force of 13 battlegroups, each 1,500 strong, dedicated to intervening mainly in African conflicts and deployable within 5Io days of political decision by the EU Council. The force would be 'explicitly but not exclusively' mandated to intervene by the UN Security Council or at the request of a government, and would be expected to enforce a cease-fire and deal with a civil or humanitarian emergency for a short period until a UN or African Union peacekeeping force could be deployed. The UK and Canada have offered to train African Union forces for deployment as peacekeepers and stabilisation forces in several African conflicts. While these initiatives would undoubtedly 
deal with some of the root causes of refugee movements in countries of origin, greater efforts are required to improve conditions for long-standing refugee populations in regions in conflict and host countries. ${ }^{42}$

Unlike direct threats, indirect threats are best addressed in the short to medium term through development initiatives and targeted assistance to alleviate the burden of hosting refugees on local communities and to ease tensions between refugees and the local community. Most often, these interventions can be small scale and highly focused. Field research by one of the authors in Kenya and Tanzania in early 2004 illustrates how such initiatives can play a role in addressing the security implications of refugee movements. UNHCR introduced a series of measures in Kenya in the late 1990s, including a mobile court system to try those suspected of criminal offences, additional support to the Kenyan police to substantially increase their presence in and around the camps at Dadaab, and the 'firewood project'.

The firewood project was designed to provide refugees with $30 \%$ of their firewood needs, with the objective of reducing the exposure of refugee women to sexual violence by reducing the amount of time they would be required to spend in the insecure areas around the camps. The six years following the introduction of the firewood project in 1998 witnessed a dramatic decline not only in the number of reported rapes in the three Dadaab camps, but also in murder and armed robbery. ${ }^{43}$ The UN and NGOs working in Dadaab believe that this improvement in refugee security and the dramatic decline in violent crime is overwhelmingly the result of the firewood project and its positive secondary benefits: creating jobs for the local population and encouraing young men who would otherwise pursue banditry to participate in the more lucrative trade in firewood.

To take another example, under the Special Programmes for Refugee Affected Areas (SPRAAs) in Tanzania and Local Assistance Programmes in Kenya assistance is targeted to the local community living near refugee camps, to not only mitigate the impact of a large refugee population, but also to demonstrate to the local population the tangible benefits of hosting refugees. The positive effects of SPRAAs have been most striking in Kibondo.

UNHCR and NGOs have spent over $\$ 1.25 \mathrm{~m}$ in Tanzania's Kibondo District alone in a range of programmes, including rehabilitation of roads used by aid convoys, improvement of water supply to local communities, development of local communication infrastructure, building of local schools and health centres, and planting of trees. A recent report by Tanzanian researchers which assesses the cost of hosting refugees against the benefits that have accrued to the local population, both directly through the SPRAAs and indirectly through the creation of employment and larger markets, concludes that the refugees have generally been a benefit. ${ }^{44}$ 
Seemingly modest activities such as SPRAAs and the firewood project have clearly contributed to an improved security and protection environment in Kenya and Tanzania, reducing competition between refugees and the local population over scarce resources and mitigating local grievances towards refugees. Such programmes, and the presence of refugees and refugee programmes more generally, could - if effectively managed - contribute significantly to longer-term local and national development. ${ }^{45}$

The World Bank notes three dimensions of poverty: lack of income and assets; voicelessness and powerlessness in the institutions of state and society; and vulnerability to adverse shocks. UNHCR argues that refugees suffer from all three conditions and that poverty can also lead refugees to a range of negative survival tactics - many of which affect local host populations - such as the degradation of the environment, prostitution, petty theft and child labour. ${ }^{46}$ Development programmes can play a key role in addressing some of these indirect security burdens, in particular providing safety nets that relieve refugees of the need to resort to these tactics.

\section{Comprehensive solutions to protracted refugee situations}

Such measures can only help manage the situation until a resolution can be found; they cannot be a substitute for a solution. The full range of possible solutions for refugees include repatriation and reintegration, local integration in the host country and resettlement to a third country.

Western donor governments could play a significant role in each of these three solutions. For example, they could support return and reintegration through local and regional post-conflict reconstruction programmes, rehabilitation of former combatants and income-generation programmes in support of demobilisation. So far, with the very recent exception of southern Sudan, donor governments have responded poorly to recent funding appeals addressing the most prominent African long-term refugee situations. UNHCR hosted a series of meetings in early March 2004 to generate international support for the repatriation of a number of African refugee populations. It argued that conditions in countries such as Somalia, Liberia, Burundi, Sierra Leone and Angola were suitable for large-scale returns in the coming years, pending positive developments in the various peace processes and in the ability of UNHCR, partner UN agencies and NGOs to build the necessary capacity in the countries of origin. When the UNHCR appealed in March 2004 for funding to prepare for the return and reintegration in several African 
countries, it received only lukewarm support. While repatriation to all the countries listed in the UNCR appeal may not be immediately possible, such prior investment is essential to ensure that the infrastructure is in place when conditions are right.

In addition, donor governments could support local integration by targeting assistance to refugee-populated areas and by supporting self-sufficiency initiatives for locally settled refugees. Sustained donor commitment to refugee integration programmes and a better understanding of political and economic constraints on many host states would encourage hosts to be more generous and innovative. Unfortunately, at present, although seven out of ten refugees are located in developing countries, assistance for them is low and erratic. Reversing this trend would be the first step to convincing over-burdened host countries to offer permanent legal status as a complement to self-sufficiency.

Governments also need to expand their overseas resettlement programmes. An adverse effect of 11 September and the 'war on terror' has been heightened screening and a dramatic reduction in the number of refugees who are resettled in the West. The United States, the world's largest resettlement country, aimed to receive 70,000 refugees in fiscal-year $2003 / 2004$ (down from 90,000 in 2000 and 142,000 in 1992), but only 52,868 were actually resettled. In addition, European states resettle fewer than 5,000 refugees a year. As a result, many refugees are left stranded in camps.

Finally, the highly selective nature of most donor funding for refugee situations requires dramatic correction. A recent study of the behaviour of donor governments argues that funding for humanitarian programmes largely reflects the foreign and domestic policies of donor governments. ${ }^{47}$ Such behaviour does not provide a coherent or effective system for financing international humanitarian activities. Donor governments give vastly disproportionate amounts of aid to a few well-known cases and far less aid to dozens of other less well-publicised refugee caseloads. The absence of an autonomous and government-assessed resource base for UNHCR, for example, continues to limit the response to present and future crises. While UNHCR has recently tried to overcome these financial constraints by accessing development funds to finance unmet needs, the results are not yet clear. Donor governments need to work towards a strengthened multilateral regime which has the mandate, capacity and resources to meet refugee needs in a more impartial and effective manner.

In the past, comprehensive approaches and greater external engagement in regions of refugee origin have proven to be the most effective way of resolving not only long-standing refugee problems but sources of regional instability. The United States and the international community employed a 
broad range of policies in the 1960s to resolve the protracted and seemingly insoluble situations of displaced persons still in camps in Europe nearly 20 years after the Second World War, and from the late 1980s to the mid-1990s in Southeast Asia to deal with the protracted Vietnamese refugee problem..$^{8}$ The benefits of a comprehensive approach in many regions of the world are potentially equally great today.

Recent major initiatives have focused on the Burundian and Somali refugee situations. The governments of Burundi and Tanzania have been working closely, since 1993, with UNHCR, through a Tripartite Agreement, to facilitate the repatriation of thousands of Burundian refugees in western Tanzania beginning in 2002. According to a UNHCR report of June 2004, almost 190,000 refugees had returned under this programme, some 50,000 in the first six months of 2004 alone. ${ }^{49}$ Simultaneously, there have been long-term political negotiations, based in Arusha, Tanzania, and guided by respected African leaders such as Julius Nyerere and Nelson Mandela, to resolve the ongoing conflict between the government in Bujumbura and a range of rebel factions. One of the primary objectives of these talks has been the holding of national elections in Burundi and the establishment of a government representing the various political and ethnic interests.

Both Tanzania and Burundi see repatriation as the only viable solution for the protracted refugee population in western Tanzania. However, repatriation alone will not resolve the problem. During the past 30 years, Burundi has experienced several violent upheavals in which hundreds of thousands of refugees have fled across Tanzania's borders. Repeated repatriations during this period have not proven to be sustainable. The causes of Burundi's recurring ethnic violence have not been fundamentally addressed in the recent negotiations, and so it is unlikely that the ongoing mass return of refugees to the densely populated and ethnically divisive country will be sustainable. It may, in fact, contribute to increased instability, notwithstanding the presence of some 5,000 UN peacekeepers.

The case of Burundi underscores the need for a well-integrated political and humanitarian approach to protracted refugee situations, in which political, strategic, economic and humanitarian initiatives are complementary and focus on common objectives. Some progress to this end has been made in the formulation of a comprehensive solution for the protracted Somali refugee situation.

Somalia has been largely neglected by the international community since the withdrawal of US forces in 1993. It has one of the lowest human development indexes in the world, and a desperate humanitarian situation. Out of a population of approximately $7 \mathrm{~m}$ people, some 400,000 are estimated to be internally displaced. Although around one million refu- 
gees have returned in the past decade, most live in conditions of absolute poverty. UN programmes for Somalia are seriously underfunded and are forced to base their operations in neighbouring countries. The presence of international agencies within Somalia itself is negligible. Recently, however, there has been some renewed international interest in restoring stability and initiating a comprehensive solution for the Somali long-term refugee population. The Under-Secretary General for Humanitarian Affairs, Jan Egland, visited Somalia in December 2004, marking the first visit of a high-level UN official to the country in over a decade.

Beginning in 2004, UNHCR initiated an international effort to try to establish a comprehensive plan of action (CPA) for Somali refugees..$^{50}$ This initiative includes most of the major stakeholders, including the newly established Somali government, host governments in the region, the European Commission, UNHCR and the co-sponsors of the action plan, Denmark, Netherlands and the UK. The steering group does not include Somaliland or Puntland. With seed funding from the European Commission, the steering group will develop a plan of action, to be approved for funding at a special inter-governmental meeting in mid-2005.

The effort to create a Somali refugee CPA is seen as a test case for solving other protracted refugee situations. At present, given the continuing instability in southern and central Somalia, the focus of the CPA is repatriation to Somaliland and Puntland, where conditions for returnees are more secure than in southern and central Somalia. However, in order for returns to be sustained there needs to be increased emphasis on reintegration and postconflict recovery. Another possibility is to tap into development funds to provide stability in areas of return, although funds for reintegration are limited and donor appeals for Somali returns have been seriously undersubscribed. For example, less than half of the $\$ 200 m$ for the 2004 Somalia repatriation appeal has been pledged so far.

The second objective of the CPA is to examine how human-rights and economic conditions for Somali refugees can be improved in host countries such as Kenya, Ethiopia, Yemen and Djibouti. A number of studies will be undertaken by local experts in the region to determine the protection and assistance gaps that need to be addressed in any future projects within the CPA. Finally, the European co-sponsors are particularly interested in examining ways to mitigate irregular movements of Somalis to the West, given that Somalis have constituted one of the largest nationalities seeking asylum in Europe over the past decade.

After 13 years of negotiations, the Mbaguthi Peace Process in Nairobi resulted in the November 2004 election of Abdullahi Yusuf Ahmed as Somalia's new president. The composition of a full cabinet was finally agreed in early 
2005. The formation of a new government does not, however, promise stability. Somaliland does not recognise the new government, and there appears to be substantial opposition from the Islamic courts and rival clans. As a result of this opposition and prevailing instability, the government has not been able to sit in Mogadishu, but remains in Kenya. Proposals for an African Union stabilisation force to provide security for the new government are contingent upon the establishment of the government in Mogadishu. There is little likelihood of such a deployment in the foreseeable future.

Insecurity remains rife; many leaders of warring factions continue to profit personally from conditions of instability. As a result, most aid agencies have pulled out of the country. Intermittent fighting among rival clans in central and southern Somalia has caused scores of deaths and injuries. There are also cases of more targeted violence: in January 2005, the police chief of Mogadishu, who supported the return of the new government and the deployment of a stabilisation force, was murdered.

\section{The need for an integrated approach}

Instability in Somalia, like the security situation in Burundi, underscores the need for 'joined-up' international policies to address the long-standing security implications of protracted refugee situations and humanitarian emergencies. While the Somali refugee CPA is a commendable effort to engage the international community on a particularly difficult and complex protracted refugee situation, it does not adequately link humanitarian factors with the underlying and crucially important economic, political and security factors. A solution for the Somali situation requires the restoration of a degree of stability and normality in southern and central Somalia, after more than a decade of instability.

The principal weakness of the Somali refugee CPA is that it remains divorced from the political developments surrounding the return to Mogadishu of the newly elected government. The CPA primarily focuses on repatriation to Somalia and improving conditions in Somalia in order to ensure that refugee returns are sustainable. However, the lessons from past comprehensive plans of action, such as those in Indochina and Central America, are that humanitarian efforts must be closely linked to political and diplomatic initiatives. Previous CPAs also required the active involvement of countries of origin so that internal conflicts and refugee problems would not reoccur. Crucially, successful CPAs relied on external political initiatives that laid the foundations for humanitarian and development programmes. Without strong political support and successful peace negotiations there is little immediate prospect of resolving protracted refugee situations such as in Somali or Burundi. Somalia and Burundi need stable central govern- 
ments, but new political roots require considerable external support to take hold. This means not only humanitarian aid but security and peacekeeping assistance that includes training and equipping a new independent police force and army, and disarming and demobilising warring factions.

The problem of Somali refugees would be a good place to begin. In this case in particular, there are strong security and political reasons for acting now. Unlike other African refugee populations, Somalis have migrated across the world and established themselves in communities in Europe and North America, creating a pull factor for new groups of Somali emigrants. Consequently, several EU governments have sought to find ways both to contain those flows and to return failed asylum seekers, if not directly to Somalia, then to Somaliland or Puntland where conditions are slightly better. Somalia has also been the target of UN arms sanctions, which have unsuccessfully tried to curb the flow of small arms from Somalia across the region. Thus, there exist strong incentives for EU and North American governments to support a combined political-humanitarian initiative to resolve the problem.

Yet the overall response of international policymakers remains compartmentalised. Security, development and humanitarian issues are discussed in different forums, each with their own theoretical frameworks, institutional arrangements and independent policy approaches. Neither the UN nor donor governments have adequately integrated the resolution of recurring regional refugee problems with the promotion of economic and political development, conflict resolution and sustainable peace and security. International involvement in nation-building, reconstruction and rehabilitation in war-torn regions is still piecemeal and under-resourced. There is a pressing need to develop a policy agenda that extends beyond conventional boundaries and seeks to integrate the resolution of chronic and recurring regional refugee problems with economic development and security issues. 


\section{Notes}

1 Dennis McNamara, Global Survey of the Humanitarian Situation of Uprooted Populations, keynote address, ECHO Seminar, Cartagena, 7 June 2004.

2 UNHCR, Protracted Refugee Situations: An Analysis of the Past Decade, Working Paper, 2004.

3 Ibid.

4 Details of the policy responses in Kenya and Tanzania were collected during field visits to Nairobi and Dadaab (2001 and 2004) and Dar es Salaam (1999 and 2004) and Kibondo (2004). Internal reports and statistics on these programmes are held on file with the authors.

5 See Aristide Zolberg, Astri Suhrke and Sergio Aguayo, Escape from Violence: Conflict and the Refugee Crisis in the Developing World, (New York: Oxford University Press, 1989).

6 For background see the collection of case studies in Hugh Brooks and Yassin El-Ayouty (eds), Refugees South of the Sahara: An African Dilemma (Westport, CT: Negro Universities Press, 1970).

7 UNHCR archives, HCR/KAM-Gen-49, Recent Influx of Refugees from Congo and Sudan into Uganda, 21 September 1964.

8 Jacques Cuenod, "The problem of Rwandan and Sudanese Refugees', in Sven Hammel, African Refugee Problems (Uppsala: The Scandanavian Institute of African Studies, 1966), pp. 345-53; and Rene Lemarchand, Rwanda and Burundi (London: Pall Mall Press, 1970).

9 See Aristide Zolberg, Astri Suhrke and Sergio Aguayo, Escape from Violence: Conflict and the Refugee Crisis in the Developing World (Oxford: Oxford University Press, 1989).

10 See Gil Loescher, The UNHCR and World Politics (Oxford: Oxford University Press, 2001).

11 See Christopher Clapham, Africa and the International System: The Politics of State Survival (Cambridge: Cambridge University Press, 1996).

12 Recent field visits by the authors to Nairobi and Dar es Salaam, for example, reveal that large numbers of refugees and displaced people live clandestinely and on the margins of society so as to avoid detection by the authorities. As a result, many host states and UNHCR country offices are unaware of the precise scale of their protracted urban refugee populations.

13 Jeff Crisp, 'Forms and Sources of Violence in Kenya's Refugee Camps', Refugee Survey Quarterly, vol. 19, no. I, 2000, pp. 54-70.

14 Kathi Austin, 'Armed Refugee Camps as a Microcosm of the Link between Arms Availability and Insecurity', Programme on Global Security and Cooperation, Workshop on International Law and Small Arms Proliferation, 6 February 2002, p. 5.

15 See Monica Kathina Jum and Peter Mwangi Kagwanja, 'Securing Refuge from Terror: Refugee Protection in East Africa after September $11^{\prime}$, in Niklaus Steiner, Mark Gibney and Gil Loescher, Problems of Protection: The UNHCR, Refugees, and Human Rights (London: Routledge, 2003), pp. 225-236.

16 See BBC News online, 'Kenya Inquiry Targets Somali Militants', 30 November 2002, http://news.bbc.co.uk/2/hi/ Africa/2529655.stm; and Danna Harman, 'In a Dire Kenyan Camp, Links to al-Qaeda', Christian Science Monitor, 18 December 2002.

17 See Beth Elise Whitaker, 'Refugees in Western Tanzania: The Distribution of Burdens and Benefits Among Local Hosts', Journal of Refugee Studies, vol. 15, no. 4, 2002, pp. 339-58; Sreeram Sundar Chaulia, 'The Politics of Refugee Hosting in Tanzania: From Open Door to Unsustainability, Insecurity and Receding Receptivity', Journal of Refugee Studies, vol. 16, no. 2, 2003, pp. 147-66; and International Crisis Group, Burundian Refugees in Tanzania: the Key Factor to the Burundi Peace Process, ICG Central Africa Report no. 12, 30 November 1999.

18 See International Crisis Group, Burundian Refugees in Tanzania. 
19 Bonaventure Rutinwa, The End of Asylum? The Changing Nature of Refugee Politics in Africa, New Issues in Refugee Research, Working Paper No. 5 (Geneva: UNHCR, May 1999).

20 US Committee for Refugees, 'Warehousing Refugees: A Denial of Rights, a Waste of Humanity', World Refugee Survey 2004 (Washington DC: USCR, 2004), pp. 38-56.

21 See Zolberg et al., Escape from Violence.

22 For a more detailed analysis of the security implications of protracted refugee situations, see the Gil Loescher and James Milner, Security Implications of Protracted Refugee Populations, Adelphi Paper no. 375 (Abingdon: Routledge for the International Institute for Strategic Studies, in press).

23 See Fionna Terry, Condemned to Repeat? The Paradox of Humanitarian Action (Ithaca, NY: Cornell University Press, 2002); Stephen Stedman and Fred Tanner, Refugee Manipulation: War, Politics and the Abuse of Human Suffering (Washington DC: Brookings Institution Press, 2002); and Jeff Crisp and Karen Jacobsen (eds), 'Security in Refugee Populated Areas', Refugee Survey Quarterly, vol. 19, no.1, 2000, pp. 3-23.

24 See Alan Dowty and Gil Loescher, 'Refugee Flows as Grounds for International Action', International Security, vol. 21, no. 1, Summer 1996, pp. 43-7I.

25 Macedonian deputy foreign minister, speaking at the Emergency Meeting on the Kosovo Refugee Crisis, Geneva, 6 April 1999.

26 Loescher, Refugee Movements and International Security, p. 42.

27 Tiyanjana Maluwa, 'The Refugee Problem and the Quest for Peace and Security in Southern Africa', International Journal of Refugee Law, vol. 7, no. 4, 1995, p. 657 .

28 Ibid.

29 See Jeff Crisp, 'Refugees and International Security', paper presented at $4^{\text {th }}$ International Security Forum, Geneva, 15-17 November 2000; and Rutinwa, The End of Asylum.
30 Rutinwa, The End of Asylum, p. 2.

31 Matthew Gibney, 'Security and the Ethics of Asylum after 11 September', Forced Migration Review, no. 13, 2002, p. 13.

32 Bonaventure Rutinwa, 'The Tanzanian Government's Response to the Rwandan Emergency', Journal of Refugee Studies, vol. 9, no. 3, 1996, p. 299.

33 Jeffrey Herbst, States and Power in Africa: Comparative Lessons in Authority and Control (Princeton, NJ: Princeton University Press, 2000) p. 3.

${ }^{34}$ Ibid. p. 255.

35 See for example William $\mathrm{O}^{\prime}$ Neill, 'Conflict in West Africa: Dealing with Exclusion and Separation', International Journal of Refugee Law, vol. 12, suppl. 1, 2000, pp. 171-94; and Bonaventure Rutinwa, 'Screening in Mass Influxes: The Challenge of Exclusion and Separation', Forced Migration Review, no. 13, June 2002, pp. 35-7.

36 Jean-Francois Durieux, 'Preserving the Civilian Character of Refugee Camps: Lessons from the Kigoma Refugee Programme in Tanzania', Track Two, vol. 9, no. 3, November 2000, pp. 25-35.

37 Roy Herrmann, 'Mid-term Review of a Canadian Security Deployment to the UNHCR Programme in Guinea', Geneva, UNHCR, Evaluation and Policy Analysis Unit, EPAU/2003/04, October 2003.

38 Jeff Crisp, 'Lessons Learned from the Implementation of the Tanzania Security Package', Geneva, UNHCR, Evaluation and Policy Analysis Unit, EPAU/2001/05, May 2001.

39 See Lisa $\mathrm{Yu}$, Separating Ex-Combatants and Refugees in Zongo, DRC: Peacekeepers and UNHCR's 'Ladder of Options', New Issues in Refugee Research, Working Paper No. 60 (Geneva, UNHCR, August 2002).

40 Mats Berdal, 'The UN After Iraq', Survival, vol. 46, no. 3, 2004, pp. 83-102. Berdal cites Kofi Annan's May 2004 speech outlining for the Security Council the multidimensional tasks of today's peacekeeping missions: 'Peacekeeping today has become 
increasingly multidimensional. The missions you mandate are implementing peace agreements, helping manage political transition, building institutions, supporting economic reconstruction, organising the return of refugees and internally displaced persons, assisting humanitarian aid programmes, supervising or even organising elections, monitoring human rights, clearing minefields, disarming and demobilising militias, and reintegrating their members into the civilian economy'.

41 Ibid.

42 See Gil Loescher and James Milner, "The Missing Link: the Need for Comprehensive Engagement in Regions of Refugee Origin', International Affairs, vol. 79, no. 3, 2003, pp. 519-617.

43 In 1998, there were over 300 reported cases of violent crime in the Dadaab camps, of which 104 were cases of rape. By 2003 , that number had fallen dramatically to 36 reported cases of violent crime, of which 15 were cases of rape.

44 Centre for the Study of Forced Migration, University of Dar es Salaam,
The Impact of the Presence of Refugees in Northwestern Tanzania (Dar es Salaam, September 2003).

45 See Karen Jacobsen, 'Can Refugees Benefit the State? Refugee Resources and African Statebuilding', Journal of Modern African Studies, vol. 40, no. 4, 2002, pp. 557-96.

46 UNHCR, 'Protracted Refugee Situations', UNHCR, Standing Committee, $30^{\text {th }}$ Meeting, 10 June 2004, EC/54/SC/CRP.14.

47 Larry Minear and Iain Smillie, The Quality of Money: Donor Behavior in Humanitarian Financing (Somerville, MA: Humanitarianism and War Project, Tufts University, April 2003).

48 See Loescher, The UNHCR and World Politics; and UNHCR, The State of the World's Refugees (Oxford: Oxford University Press, 2000).

49 UNHCR, 'Press Release: New Border Crossing Drums up Interest in Burundian Return', 24 June 2004.

50 This section on the Somalia CPA is based upon authors' interviews with staff of UNHCR Africa Bureau, Geneva, September 2004. 